\title{
Examination of resistance to Sclerotinia stalk and head rot in sunflower (Helianthus annuus L.) hybrids
}

\author{
Viktor József Vojnich - Attila Hüvely - András Palkovics \\ Kecskemét College, Faculty of Horticulture, Department of Horticulture, Kecskemét, Hungary \\ vojnich.viktor@kfk.kefo.hu
}

\begin{abstract}
SUMMARY
Nowadays, phytopathogenic fungi cause the most serious yield loss in open field cultures, and sunflower (Helianthus annuus) is no exception to this phenomenon. Sclerotinia stalk and head rot (Sclerotinia sclerotiorum) is present in the whole area of Hungary, and can cause serious financial loss. In our experiment, sunflower hybrids were tested for resistance to Sclerotinia sclerotiorum infection. 16 sunflower hybrids were examined at the Experimental Breeding Site in Jászboldogháza. Pesticide treatment and also nutrient replacement were applied on the sunflower fields.
\end{abstract}

Keywords: sunflower hybrids, Helianthus annuus, open field trial, Sclerotinia sclerotiorum

\section{INTRODUCTION}

The sunflower (Helianthus annus) gene center can be found in the west side of North America, but the first man who nationalized in Europe was a russian tsar Peter I. in the XVIII: century (Zhukovsky, 1950). Related to the extension of the arable farm area, oil mills have been spread and lots of local sunflower variety has occurred (Walter, 1974). When gene selection has been started here in the middle of the XIX century, it has immediately great success (Pustovojt, 1964). In Hungary the most significant habitats of sunflower were in the east-north counties (Szabolcs-Szatmár-Bereg, Borsod, Hajdú-Bihar) and in Transylvania. Thanks to the specific site and the orthodox religion (Kurnik, 1969) the first oil mill was established in 1812 in Ercsi, followed by many others.

Primarily sunflower was sown because of its high oil content (Antal, 1992; Bocz, 1992). It has been used in catering, animal feeding, and industrial purposes (colour stain, insecticide, cosmetics) (Vranceanu, 1977; Frank, 1999). Most of all: sunflower is a good honey plant and excellent to use like fuel substituted.

Today sunflower is a considerable plant among filed crops too. In the last decades crop area has grown in a huge rate worldwide (Antal, 2005), as long as the sunflower growing area in Hungary (2005-2014) is the same (Table 1). While sunflower crop yield might be 5-6 t/ha by applied suitable and effective production methods, then the Hungarian yield is approximately 2-3 t/ha.

Sunflower production area, cumulated and mean yield (2005-2014) in H
\begin{tabular}{|c|c|c|c|}
\hline Year & $\begin{array}{c}\text { Production area } \\
(1000 \mathrm{ha})\end{array}$ & $\begin{array}{c}\text { Cumulated } \\
(1000 \mathrm{t})\end{array}$ & $\begin{array}{c}\text { Mean } \\
(\mathrm{t} / \mathrm{ha})\end{array}$ \\
\hline 2005 & 511 & 1.108 & 2.170 \\
\hline 2006 & 534 & 1.181 & 2.210 \\
\hline 2007 & 513 & 1.060 & 2.070 \\
\hline 2008 & 550 & 1.468 & 2.670 \\
\hline 2009 & 535 & 1.256 & 2.350 \\
\hline 2010 & 502 & 0.970 & 1.930 \\
\hline 2011 & 580 & 1.375 & 2.370 \\
\hline 2012 & 615 & 1.317 & 2.140 \\
\hline 2013 & 597 & 1.484 & 2.490 \\
\hline 2014 & 594 & 1.597 & 2.690 \\
\hline
\end{tabular}

Table 1

Source: KSH, 2015 (http)

The reason to lose crop yield is a phytopathogenic fungus, Sclerotinia sclerotiorum, which can be found everywhere in the country and may cause great economic losses. Water-soaked soft rot of sunflower can be affected to all parts of the plant, which can easily spread in vaporous, warm, rainy weather. In rare cases initial infestation can be found like flagging, necrosis (Figure 1). Later on tissues of stalks can be decayed and and heads can broken down (Antal, 2005).

\section{MATERIALS AND METHODS}

Our small plot tests were made in an experimental station in Jászboldogháza (Jász-Nagykun-Szolnok county), where we checked 16 sunflower hybrid resistance against to Sclerotinia sclerotiorum. We sown the 
hybrids in 70x30 cm of each other; one test field plot was $25.76 \mathrm{~m}^{2}$. Sowing time was on 4-6 $6^{\text {th }}$ May in 2011 by 120 seeds per plot. The experimental design was a randomized blocks with 4 repetitions. The soil type was chernozem, with a $3.7 \mathrm{~m} / \mathrm{m} \%$ humus content, and $7.3 \mathrm{pH}$ value. Nutrient supply were given in 2 periods: the first in the autumn ( $4^{\text {th }}$ November 2010) with a multinutrient fertilizer $300 \mathrm{~kg} / \mathrm{ha}$, and the second in the spring $\left(21^{\text {th }}\right.$ February 2011) with nitrogen fertilizer $\left(\mathrm{NH}_{4}-\mathrm{NO}_{3} 34 \%\right) 200 \mathrm{~kg} / \mathrm{ha}$ active substance. Chemical treatments were

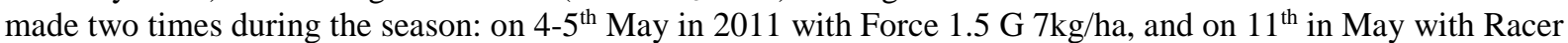
2.5 l/ha. There was no fungicide application on the area. The previous plants were rape in the year of 2008/2009 and winter wheat in 2007/2008.

Temperature and precipitation was an average of many years, which were advantageous for the sunflower hybrids from germination to the milk ripeness (15.5 mm in April, $30.6 \mathrm{~mm}$ in May, $45 \mathrm{~mm}$ in June, 91.2 in July and 39.2 in August).

Evaluation was made shortly after the symptoms have developed, on $15^{\text {th }}$ in July.

\section{RESULTS}

Among the sunflower hybrids infestation were appeared in different values. Because rainy weather promoted the infection by ascospores, symptoms could be observed both on stalks and heads (Table 2).

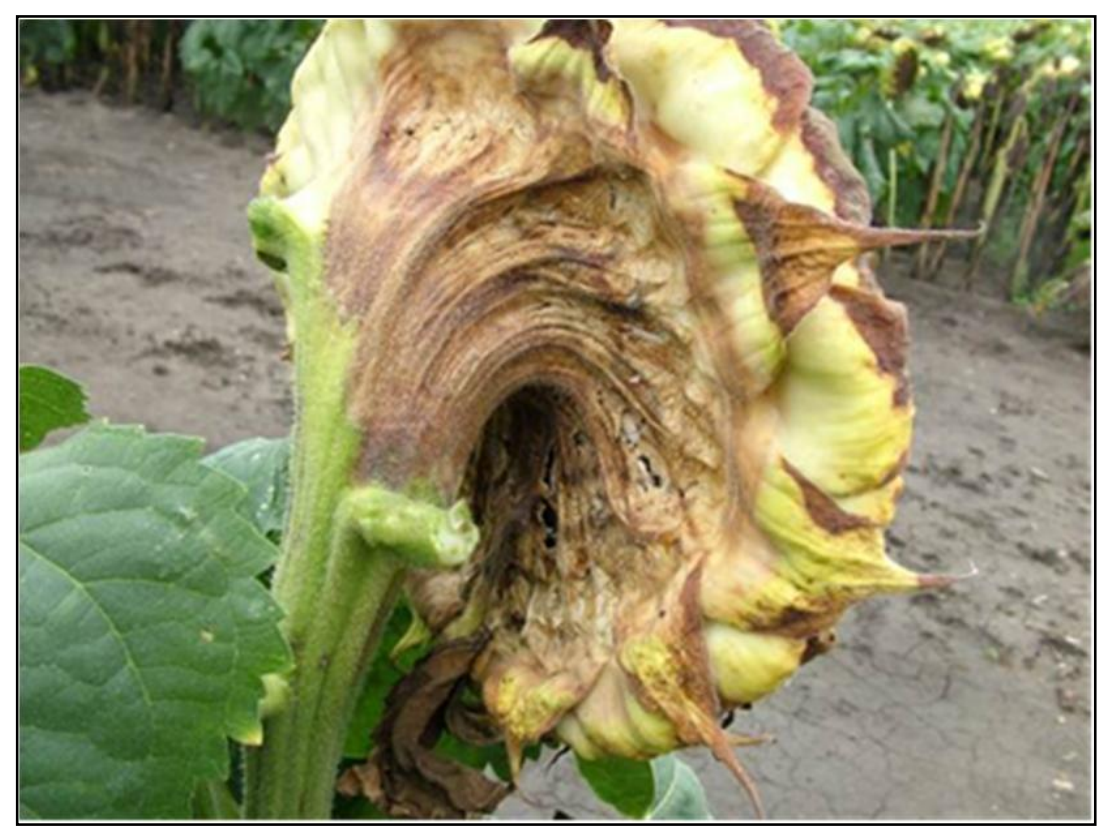

Figure 1: Sclerotinia sclerotiorum infection in sunflower head

\section{DISCUSSION}

Today the number of certificated sunflower hybrids is more than 100 . Our goal was to prove which hybrids process good resistance against Sclerotinia infections. In comparison of the tested hybrids the most resistant was 'Tamara' (6 stalk and 66 head infections). There were high head infection at the following hybrids: 'Sorenzo' (23 cases), 'Alibro' (17 cases), 'Maestro' (17 cases). The greatest stalk infection was occurred at the hybrid called 'Celia' (9 cases). The most resistant sunflower hybrid against Sclerotinia sclerotiorum were 'Luleo' and 'Neoma' considering both infection types.

This evaluation test was given a general impression about the whole course of infection, which can be useful for breeders in the future. 
Sclerotinia stalk and head rot in sunflower (Helianthus annuus L.) hybrids

\begin{tabular}{|c|c|c|c|c|c|c|}
\hline Name of hybrid & Infection type & $\begin{array}{c}\text { I. } \\
\text { repetition }\end{array}$ & $\begin{array}{c}\text { II. } \\
\text { repetition }\end{array}$ & $\begin{array}{l}\text { III. } \\
\text { repetition }\end{array}$ & $\begin{array}{l}\text { IV. } \\
\text { repetition }\end{array}$ & $\begin{array}{c}\text { Total } \\
\text { number }\end{array}$ \\
\hline \multirow[t]{2}{*}{ 1. Neoma st. } & Sclerotinia stalk rot & 2 & 0 & 1 & 0 & 3 \\
\hline & head rot & 0 & 0 & 1 & 0 & 1 \\
\hline \multirow[t]{2}{*}{ 2. Ferti st. } & Sclerotinia stalk rot & 5 & 0 & 1 & 1 & 7 \\
\hline & head rot & 0 & 6 & 2 & 0 & 8 \\
\hline \multirow[t]{2}{*}{ 3. Brio st. } & Sclerotinia stalk rot & 2 & 0 & 1 & 1 & 4 \\
\hline & head rot & 1 & 1 & 4 & 1 & 7 \\
\hline \multirow[t]{2}{*}{ 4. P 102 CL st. } & Sclerotinia stalk rot & 2 & 1 & 3 & 1 & 7 \\
\hline & head rot & 4 & 2 & 0 & 5 & 11 \\
\hline \multirow[t]{2}{*}{ 5. Celia st. } & Sclerotinia stalk rot & 1 & 0 & 6 & 2 & 9 \\
\hline & head rot & 3 & 1 & 2 & 1 & 7 \\
\hline \multirow[t]{2}{*}{ 6. Sunflora st. } & Sclerotinia stalk rot & 0 & 1 & 5 & 0 & 6 \\
\hline & head rot & 2 & 0 & 2 & 0 & 4 \\
\hline \multirow[t]{2}{*}{ 7. Tamara st. } & Sclerotinia stalk rot & 3 & 0 & 1 & 2 & 6 \\
\hline & head rot & 14 & 17 & 15 & 20 & 66 \\
\hline \multirow[t]{2}{*}{ 8. Kendo } & Sclerotinia stalk rot & 2 & 0 & 2 & 0 & 4 \\
\hline & head rot & 0 & 2 & 3 & 0 & 5 \\
\hline \multirow[t]{2}{*}{ 9. Palomino } & Sclerotinia stalk rot & 2 & 0 & 3 & 0 & 5 \\
\hline & head rot & 1 & 2 & 2 & 3 & 8 \\
\hline \multirow[t]{2}{*}{ 10. Alibro } & Sclerotinia stalk rot & 2 & 1 & 0 & 1 & 4 \\
\hline & head rot & 3 & 5 & 3 & 6 & 17 \\
\hline \multirow[t]{2}{*}{ 11. Lisboa } & Sclerotinia stalk rot & 3 & 1 & 2 & 1 & 7 \\
\hline & head rot & 8 & 1 & 0 & 1 & 10 \\
\hline \multirow[t]{2}{*}{ 12. Maestro } & Sclerotinia stalk rot & 2 & 0 & 1 & 1 & 4 \\
\hline & head rot & 1 & 6 & 7 & 3 & 17 \\
\hline \multirow[t]{2}{*}{ 13. Oslo } & Sclerotinia stalk & 2 & 0 & 4 & 1 & 7 \\
\hline & head rot & 0 & 0 & 1 & 5 & 6 \\
\hline \multirow[t]{2}{*}{ 14. Luleo } & Sclerotinia stalk rot & 0 & 0 & 0 & 1 & 1 \\
\hline & head rot & 2 & 0 & 0 & 0 & 2 \\
\hline \multirow[t]{2}{*}{ 15. Sorenzo } & Sclerotinia stalk rot & 1 & 0 & 2 & 0 & 3 \\
\hline & head rot & 8 & 3 & 7 & 5 & 23 \\
\hline \multirow[t]{2}{*}{ 16. Pan 31-101 } & Sclerotinia stalk & 1 & 0 & 1 & 1 & 3 \\
\hline & head rot & 2 & 1 & 2 & 4 & 9 \\
\hline Total & & 79 & 51 & 84 & 67 & 281 \\
\hline
\end{tabular}




\section{ACKNOWLEDGEMENTS}

This work was supported by Experimental Breeding Site in Jászboldogháza. Thanks for Ádám Antal, student of Kecskemét College.

\section{REFERENCES}

Antal, J. (1992): Napraforgó In: Bocz E. Szántóföldi növénytermesztés Mezőgazda Kiadó, Budapest

Antal, J. (2005): Növénytermesztéstan 2. Gyökér- és gumós növények, Hüvelyesek, Olaj- és ipari növények, Takarmánynövények. Mezőgazda Kiadó, Budapest

Bocz, E. (1992): Szántóföldi növénytermesztés. Mezőgazda Kiadó, Budapest

Frank, J. (1999): A napraforgó biológiája, termesztése. Mezőgazda Kiadó, Budapest

Kurnik, E. (1969): Napraforgó. p. 264-285. In: Kapás S. (Szerk.) Magyar Növénynemesítés, Budapest: Akadémia Kiadó. 285 pp.

Pustovojt, V.S. (1964): Conclusions of work on the selection and seed productin of sunflowers. Agrobiology, 5: 662-697.

Vranceanu, A.V. (1977): A napraforgó. Mezőgazda Kiadó, Budapest

Walter, H. (1974): Die Vegetation Osteuropas. Nord- und Zentralasiens. Vegetationsmonographien der einzelnen Grossraume. Stuttgart: Gustav Fischer Verlag. p. 452.

Zhukovszky, P.M. (1950): Cultivated plants and their wild relatives. (Kulturnüe rasztenija i ih gyikie szorodicsi.) Moszkva, Akad. Izd. 732 pp.

http://www.ksh.hu/docs/hun/xstadat/xstadat_eves/i_omn007.html 